\title{
EXPERIMENTS ON FREEZE-BONDING BETWEEN ICE BLOCKS IN FLOATING ICE RUBBLE
}

\author{
By R. ETTEMA \\ (Iowa Institute of Hydraulic Research, Department of Civil and Environmental Engineering, \\ University of Iowa, Iowa City, Iowa 52242, U.S.A.) \\ and J.A. SCHAEFER \\ (Department of Physics and Engineering Science, Loras College, Dubuque, Iowa 52001, U.S.A.)
}

\begin{abstract}
Series of experiments were conducted with the aim of determining the influences of the following factors on freeze-bonding between contacting ice blocks in floating ice rubble: pressure normal to the contact plane, period and area of contact, and salinity of the water in which freeze-bonding occurred. Freeze-bonding between ice blocks in air was also investigated. The experiments were conducted with water and air temperatures of about $0^{\circ} \mathrm{C}$ and normal pressures, between ice blocks, up to $4 \mathrm{kPa}$. This range of normal pressures may occur hydrostatically between ice blocks in layers of floating ice rubble up to about $10 \mathrm{~m}$ thick, or in $2-3 \mathrm{~m}$ thick layers which are in a passive Rankine state of pressure. The experiments show that stronger freeze-bonds develop between ice blocks in distilled water, tap water, and water from the Iowa River than develop between ice blocks contacting in air at $0^{\circ} \mathrm{C}$. However, stronger freeze-bonds developed in air at $0^{\circ} \mathrm{C}$ than developed between ice blocks in $0^{\circ} \mathrm{C}$ saline $(\mathrm{NaCl})$ solutions with salinities in excess of $12.5 \%$ by weight. The strength of freeze-bonding increased linearly with contact period for ice blocks in distilled, tap, and river waters, but did not increase with contact period for ice blocks contacting in saline solutions or in air. The results of the experiments are useful contributions to explanations of the shear-strength behavior of a layer of floating ice rubble. For example, thicker layers of ice rubble may show greater cohesive behavior, because normal pressures and thus freezebond strengths increase with layer thickness.
\end{abstract}

RÉsumé. Expérimentations sur l'agrégation par regel entre blocs dans la blocaille de glace flottante. Des séries d'expériences ont été menées dans le but de déterminer l'influence des facteurs suivants sur l'agrégation par regel entre les blocs en contact dans la blocaille de la glace flottante: pression normale sur le plan de contact, durée et surface de contact et salinité de l'eau dans laquelle se produit ce collage par regel. L'agrégation par regel entre les blocs dans l'air a aussie été examinée. Les expériences ont eu lieu avec des températures de l'eau et de l'air voisines de $0{ }^{\circ} \mathrm{C}$ et des pressions normales entre blocs, supérieures à $4 \mathrm{kPa}$. Ce domaine de pressions normales peut exister entre les blocs disposés en couches dans la blocaille de glace flottante sur des hauteurs de $10 \mathrm{~m}$ d'épaisseur ou sur des couches de 2 à $3 \mathrm{~m}$ qui se trouvent en état de pression passive de Rankine. Ces expériences montrent qu'un collage par regel se développe plus intensément entre blocs placés dans de l'eau distillée, de l'eau du robinet, et de l'eau

\section{INTRODUCTION}

Laboratory studies (e.g. by Uzuner (1974), Tatinclaux and Cheng (1978), and more recently by Hellman (1984)) show that the shear strength and deformation behavior of a relatively thick (block size being small compared to layer thickness) layer of floating ice rubble may be described using a Mohr-Coulomb relationship involving a term for apparent cohesion. Additionally, these studies show that provenant de la Iowa River, qu'il ne se développe entre blocs en contact dans l'air à $0^{\circ} \mathrm{C}$. Cependant, une agrégation se développe plus intensément dans l'air à $0^{\circ} \mathrm{C}$ qu'elle ne le fait à $0^{\circ} \mathrm{C}$ avec des blocs en présence de solutions salines $(\mathrm{NaCl})$ pour des salinités supérieures à $12,5 \%$ en poids. La solidité du soudage par regel croît linéairement avec la durée du contact en eau distillée, de robinet et de rivière, par contre elle ne crôt pas en fonction du temps de contact pour des blocs placés dans une solution saline ou dans l'air. Les résultats de ces expérimentations constituent une contribution utile à l'explication du comportement résistant de la couche de glace flottante en blocs. Par exemple des couches de glaces de blocaille plus épaisses peuvent présenter un comportement plus cohésif, par suite des pressions normales et de là des résistances de soudages qui augmentent avec l'épaisseur de la couche.

ZUSAMMENFASSUNG. Versuche zum Zusammenfrieren von Eisblöcken im schwimmenden Eisschutt. Versuchsreihen wurden angestellt mit dem $\mathrm{Ziel}$, den Einfluss der folgenden Faktoren auf das Zusammenfrieren von sich berührenden Eisblöcken in schwimmendem Eisschutt zu bestimmen: Normaldruck an den Kontaktflächen, Dauer und Fläche des Kontaktes, Salzgehalt des Wassers, in dem der Gefriervorgang stattfindet. Zusammenfrieren von Eisblöcken in Luft wurde ebenfalls untersucht. Die Versuche wurden bei Wasser- und Lufttemperaturen von etwa $0^{\circ} \mathrm{C}$ und unter Normaldruck bis zu $4 \mathrm{kPa}$ zwischen den Eisblöcken durchgeführt. Dieser Normaldruckbereich dürfte hydrostatisch zwischen Eisblöcken in Schichten schwimmenden Eisschuttes bis $10 \mathrm{~m}$ Dicke oder in $2-3 \mathrm{~m}$ dicken Schichten, die sich in einem passiven Rankine-Druckzustand befinden, auftreten. Die Versuche zeigen, dass sich stärkere Frostbindungen zwischen Eisblöcken in destilliertem Wasser, Leitungswasser und Wasser aus dem Iowa River bilden als zwischen Eisblöcken in Luft bei $0^{\circ} \mathrm{C}$. Doch entwickeln sich stärkere Frostbindungen in Luft bei $0^{\circ} \mathrm{C}$ als zwischen Blöcken in Salzlösungen $(\mathrm{NaCl})$ bei $0^{\circ} \mathrm{C}$ mit einem Salzgehalt von mehr als 12,5 Gewichtsprozent. Die Stärke der Frostbindung wuchs linear mit der Kontaktzeit für Eisblöcke in destilliertem, Leitungs- und Flusswasser, jedoch nicht bei Eisblöcken in Salzlösungen oder Luft. Die Versuchsergebnisse sind ein nützlicher Beitrag für die Erklärung des Verhaltens der Scherfestigkeit einer Schicht schwimmenden Eisschuttes. So könnem z.B. dickere Schichten eine grössere Kohäsion aufweisen, weil der Normaldruck und damit die Stärke der Frostbindung mit der Schichtdicke zunimmt.

shear-rate strongly affects the shear strength of a layer of ice rubble. One explanation for the cohesive behavior of a layer of floating ice rubble, and for the effect of shear-rate on shear strength, is the development of freeze-bonds between adjoining, contacting ice blocks.

Consider two ice blocks, both with side dimensions of unity, brought in contact as illustrated in Figure 1. If the blocks are loaded with a normal force which produces a normal pressure $\sigma$, then subsequent to a period $t$ after 


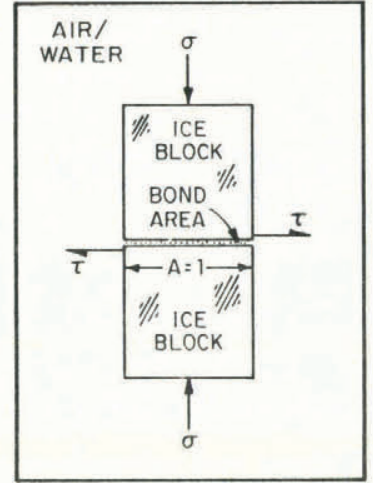

Fig. 1. Contact between two ice blocks.

application of $\sigma$, the two blocks would have to be separated at their interface by a shearing force which produces a shear stress $\tau$ across the bond. In order for the blocks to be separated, $\tau$ would have to overcome the shear strength of a freeze-bond between the blocks.

The aim of this study is to determine the dependence of freeze-bond strength $\tau$ on normal pressure $\sigma$, contact time $t$, fluid - air, pure water, or saline water - surrounding the two ice blocks, and contact area. The range of normal pressures was limited to a maximum value of $4 \mathrm{kPa}$, averaged over the nominal contact area. This value is within the range of pressures that may develop in layers of ice rubble up to about $9 \mathrm{~m}$ thick and in a neutral Rankine state. The temperature of the fluid - air, water - surrounding the blocks was held at $0^{\circ} \mathrm{C}$.

\section{BACKGROUND}

It is helpful to the understanding of the ensuing study to outline the nature of ice-rubble strength. Immediately after its formation, a layer of floating ice rubble undergoing deformation behaves similarly to a deformed granular medium. Its shear strength results from the mechanical friction and rolling resistance, and cohesion between ice blocks in contact. For this reason, most attempts (e.g. Keinonen and Nyman, 1978; Prodanovic, 1979; Hellman, 1984) to date at formulating shear strength of rubble have expressed it in the form of the Mohr-Coulomb relationship:

$$
\tau=c+\sigma \tan \phi
$$

where $\tau$ is the shear strength, $c$ the cohesive intercept, $\sigma$ the compressive stress normal to the shear plane, and $\phi$ the angle of internal resistance.

As soon as the rubble comes to rest after its formation, adjacent ice blocks may start to freeze to each other at their points of contact, and form a rigid matrix known as consolidated rubble. Because most of the rubble is submerged, the surfaces of the ice blocks are at the melting temperature. Consequently, freezing can seemingly occur with little or no heat transfer. This freezing diffusion of submerged boundaries into each other begins immediately and continues so that, with the passing of time, the freezebonds strengthen and the shear strength of the consolidated rubble increases. It is important to note here that temperature distribution through contacting ice blocks likely affects freeze-bonding, For this reason, it may be difficult to extrapolate the results on freeze-bond strength to ice rubble of different temperatures and sizes.

It is evident that any factor which leads to more intimate contact between ice blocks will produce more extensive surface-contact area between ice blocks and increase the shear strength of the layer, as well as, possibly, the freeze-bond between the ice blocks. Therefore, $\tau$ will be a function of $\sigma$, not only for its role of increasing the mechanical friction of the rubble but also because a large o decreases rubble porosity, $\eta$, and increases surface contact area and, thereby, also $c$. The intrinsic cohesion, $c$, of a layer of floating ice rubble is a function of contact period, $t$, compressive pressure $\sigma$, as well as shape, roughness, and packing of ice blocks. Additionally, $c$ will be influenced by the temperature and salinity of the water in which the layer of ice rubble floats.

Understanding the nature of freeze-bonding between ice blocks is important for understanding the shear-strength and deformation behavior of a floating layer of ice rubble. Surprisingly little is known about the intrinsic cohesion between blocks of ice, and there have apparently been no investigations on the strength of bond formed between ice block on ice block. A considerable number of studies (e.g. by Oksanen, 1983) have been conducted to determine the strength of ice bonding to other materials.

Merino (1974), Uzuner and Kennedy (1976), Mellor (1980), and others have shown that the vertical component of the internal stresses with a layer of floating ice rubble can be written as

$$
\sigma_{z}=(1-p) \rho_{\mathrm{i}} g z, \quad \text { for } 0 \leqslant z \leqslant \rho_{\mathrm{i}} h,
$$

and

$$
\sigma_{z}=(1-p)\left(\rho_{\mathrm{w}}-\rho_{\mathrm{i}}\right) g(h-z), \text { for } z \geqslant \frac{\rho_{\mathrm{i}}}{\rho_{\mathrm{w}}},
$$

in which $p$ is porosity of the layer, $\rho_{\mathrm{i}}$ and $\rho_{\mathrm{w}}$ are the densities of the ice blocks and water, respectively, $h$ is total thickness of layer of ice rubble, and $z$ is distance below the top surface of ice-rubble layer. Equations (2a) and (2b) express average stress at any level through a layer of floating rubble. Locally, contact stresses may be somewhat higher.

Figure 2 depicts a simplified layer of ice rubble. If the

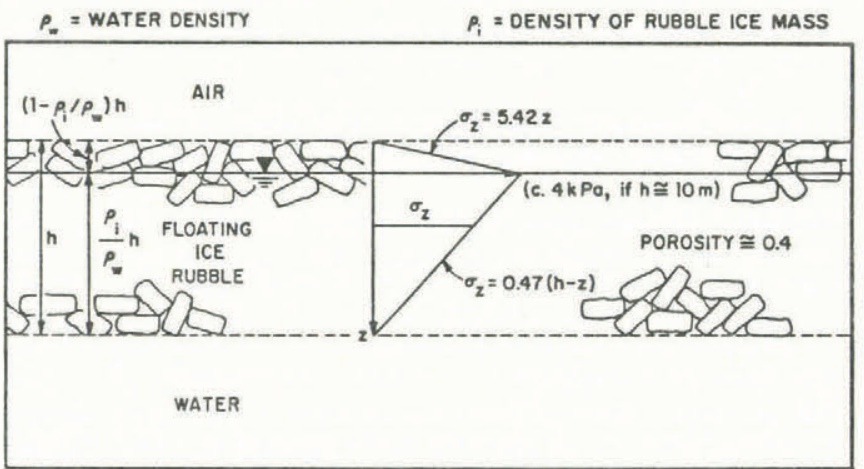

Fig. 2. Pressures within layers of floating ice rubble.

following values are assumed, $p=0.40, \rho_{\mathrm{W}}=10^{3} \mathrm{~kg} / \mathrm{m}^{3}$, $\rho_{\mathrm{i}}=0.92 \times 10^{3} \mathrm{~kg} / \mathrm{m}^{3}$, then Equation (2a) becomes

$$
\sigma_{z}=5.42 z \quad \ldots(\mathrm{kPa} \text {, with } z \text { in } \mathrm{m})
$$

and Equation $(2 \mathrm{~b})$ becomes

$$
\sigma_{z}=0.471(h-z) \ldots(\mathrm{kPa} \text {, with } h \text { and } z \text { in } \mathrm{m}) .
$$

The relationship between $\sigma_{z}$ and $z$ is indicated in Figure 2 . For the present study, the development of freeze-bonds is examined for compressive, or normal, pressures up to about $4 \mathrm{kPa}$. As is suggested in Figure 2, this range of compressive pressures is commensurate with vertical stress, $\sigma_{z}$, acting through ice-rubble layers up to $10 \mathrm{~m}$ thick. With regard to lateral pressures acting through a layer of ice rubble, $0-4 \mathrm{kPa}$ is commensurate with passive pressures acting through layers up to $(10 \mathrm{~m}) / K_{\mathrm{p}}$ thick. The coefficient of Rankine-state passive pressure, $K_{\mathrm{p}}$, varies from about 3 to 8 for values of angle of internal resistance ranging from $30^{\circ}$ to about $50^{\circ}$. The range of normal pressures used for the present study covers much of the range for layers of floating ice rubble commonly encountered in Nature.

The phenomenon of freeze-bonding between ice blocks, or ice particles, is well known and has been investigated by such noted physicists as Michael Faraday and James Thomson. Most of research effort has been concentrated on 
investigations of freeze-bonding between suspended particles of ice (e.g. Faraday, 1859; Thomson, 1861), especially spheres of ice (e.g. studies by Nakaya and Matsumoto, 1954; Jensen, 1956; Kingery, 1960; Kuroiwa, 1961; Hobbs and Mason, 1964).

The mechanism causing ice pieces to be adhesive, and hence the cohesive behavior of a layer of ice rubble, has been the topic of considerable interest and debate. Hobbs (1974) and Pounder (1965), among others, provided detailed discussions on freeze-bonding. Faraday ascribed freezebonding to the freezing of a "liquid-like" layer (term used by Hobbs) at the interface of two moist ice pieces. Thomson attributed freeze-bonding to pressure melting at the contact between two ice pieces.

More recently, the process of sintering, or cold welding, has been used to explain the growth of a freeze-bond between contacting ice pieces, especially for pieces surrounded by air. Kingery (1960) and Kuroiwa (1961), for example, used this explanation for freeze-bonding.

When two contacting ice pieces are pressed against each other (e.g. as in Fig. 1), pressure melting may also come into play. If the pressure remains on the ice pieces, pressure melting may cause the two ice pieces to seat in closer contact, and the pressure may cause a sandwiched film of water to be squeezed from between the ice pieces. The upshot of the pressure would be the more rapid development of a stronger freeze-bond.

If the two moist ice pieces are surrounded by air, freezing of the water film at the contact may cause the two pieces to become fused to one another. Thereafter, the fusion would grow principally through the action of diffusion through the vapor phase of water, as was proposed by Hobbs and Mason (1964).

If a freeze-bond did not form between two ice blocks, static friction would have to be overcome in order to slide them apart. The shear stress to overcome static friction and separate the two blocks can be stated as

$$
\tau_{\mathrm{f}}=\mu_{\mathrm{s}} \sigma
$$

where $\mu_{\mathrm{s}}$ is the coefficient of static friction, for which a value of about 0.1 is reasonable (Hobbs, 1974), and $\sigma$ is normal pressure. Values of $\tau_{f}$ up to about $0.1 \times 4 \mathrm{kPa}=$ $400 \mathrm{~Pa}$ would be required to separate two blocks under a normal load of $4 \mathrm{kPa}$.

The strength of the freeze-bond between two smooth ice blocks in water and in air is examined in the discussion that follows.

\section{EXPERIMENTS}

The experiments were conducted in a cold room at the Iowa Institute of Hydraulic Research (IIHR). For all tests, the air temperature in the cold room was held between $-1^{\circ}$ to $+1^{\circ} \mathrm{C}$.

Ice blocks of repeatable size and smoothness were produced from mains tap water frozen in smooth aluminum casts. Three sizes of cast were used. The casts were filled with tap water and placed in a freezer box which was maintained at an internal air temperature of $-10^{\circ} \mathrm{C}$. The base areas of the three sizes of ice blocks were $4.52 \times$ $10^{-3} \mathrm{~m}^{2}, 9.03 \times 10^{-3} \mathrm{~m}^{2}$, and $19.35 \times 10^{-3} \mathrm{~m}^{2}$, such that the relative sizes of the base areas were $1: 2: 4$ (see Fig. 3). Although the base of each block was as smooth and planar as the aluminum mold in which it was cast, the upper surface of each block was rounded due to expansion of the water from which it was formed. The top surface was leveled with a heated iron, using the method suggested by Oksanen and Keinonen (1982).

For each experiment, the test block of ice was placed on a smooth lower slab of ice $0.71 \mathrm{~m}$ long, $0.28 \mathrm{~m}$ wide, and $0.05 \mathrm{~m}$ thick. The lower slab of ice was prepared in a similar manner as that used to produce the test blocks of ice. It was grown in an aluminum container. The surface in contact with the base of the aluminum container was upward and used during the experiments. The surface which was exposed to air, during the growth of the block, and expanded outwards was leveled using a heated iron. This leveled face was in contact with the base of the glass-sided test tank.

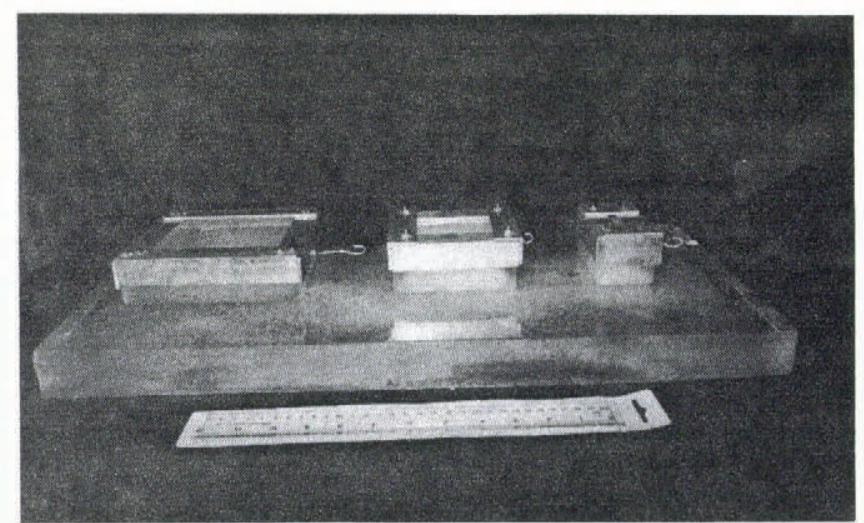

Fig. 3. Samples of the test blocks of ice.

Aluminum frames were constructed to fit over the top of each size of test block of ice, as shown in Figure 4. The frames were fitted with a hook which was located at the center of the front face of each test block. The experimental set-up is illustrated in Figure 4. A light-weight, stainless steel-strand cable was attached to the hook and

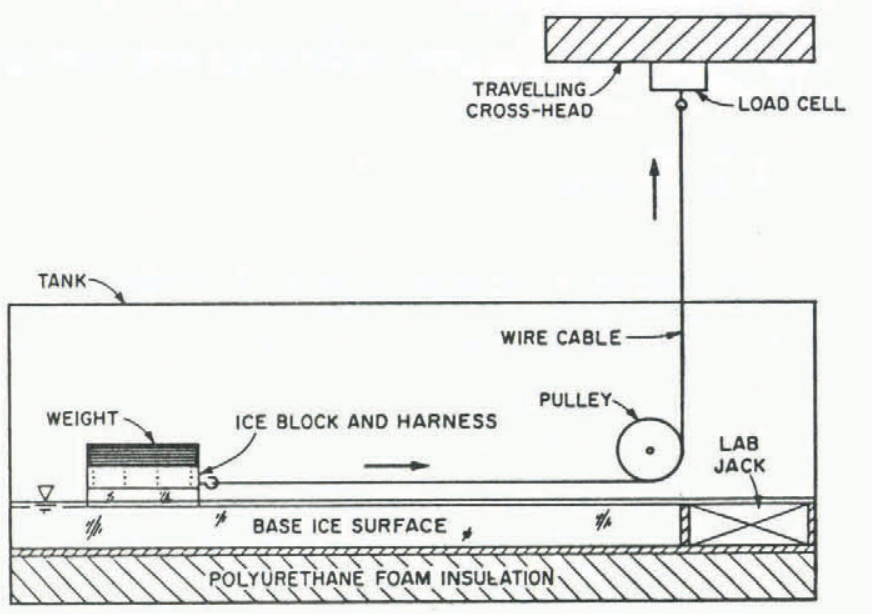

Fig. 4. The experimental set-up.

passed around a pulley, which guided the cable to a load cell rigidly mounted on the traveling cross-head of a Tinius Olsen universal testing machine. When the cross-head of the testing machine was moved upward, the increasing cable tension was transduced by way of the load cell. The output voltage from the load cell was fed to a signal conditioner which was connected to the IIHR HP1000 computer. Most tests were conducted with the cross-head moving at a speed of $0.84 \mathrm{~mm} / \mathrm{s}$. A brief series of tests was conducted with the cross-head moving at a speed of $0.44 \mathrm{~mm} / \mathrm{s}$.

The load cell was calibrated periodically throughout the experiments and was used to a precision of $\pm 0.10 \mathrm{~N}$. A typical time history of tension in the cable is shown in Figure 5.

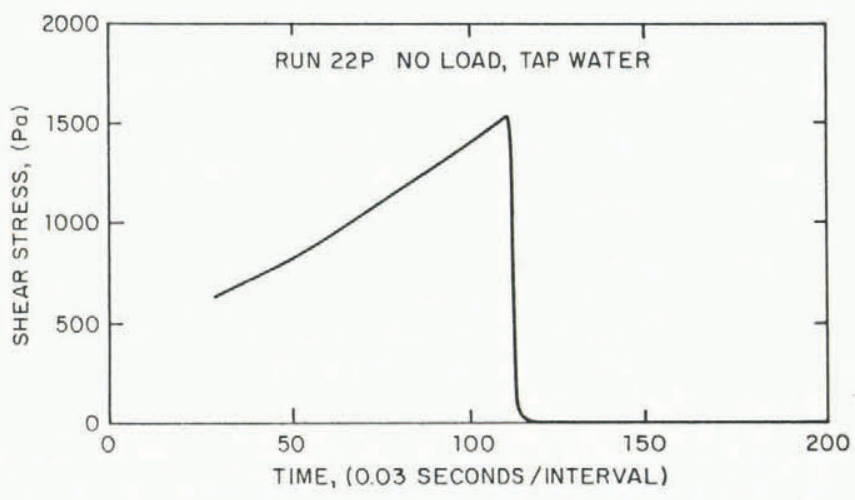

Fig. 5. A typical time history of cable tension. 


\section{TABLE I. PROGRAM OF EXPERIMENTS}

\section{Effect of loading rate}

a. Cross-head speed of $0.84 \mathrm{~min} / \mathrm{s}$

b. Cross-head speed of $0.44 \mathrm{~min} / \mathrm{s}$

2. Effect of period of bonding (0-4 min)

a. In air

b. In distilled water

c. In tap water

d. In $3 \%$ salinity water

e. In $12.5 \%$ salinity water

f. In $25 \%$ salinity water

g. In Iowa River water

\section{Effect of normal pressure $(0-4 \mathrm{kPa})$}
a. In air
b. In distilled water
c. In tap water
d. In $3 \%$ salinity water
e. In $12.5 \%$ salinity water
f. In $25 \%$ salinity water
g. In Iowa River water

4. Effect of contact area using blocks having area ratios of $1: 2: 4$

a. In air

b. In tap water

The program of experiments, which is summarized in Table I, involved series of experiments to determine the effects on freeze-bonding of the following parameters:

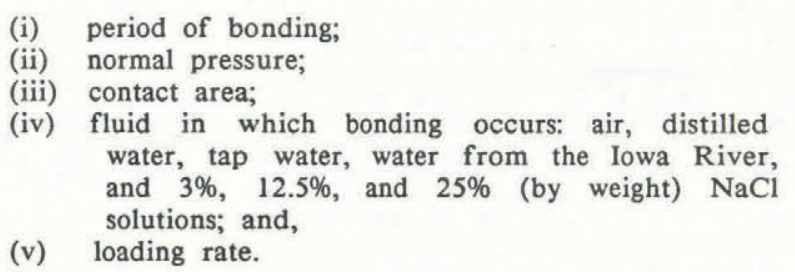

In general, the experimental procedure that was adopted conformed to the procedure specified in the IAHR recommendations on testing methods of ice properties (1980): in accordance with the section on testing for friction coefficient between ice and some material, a test block of ice was seated on and towed over dry and wet surfaces of ice, which were horizontally aligned. The initial peak resistance (see Fig. 5) was taken to be the shear strength of the freeze-bond between the test block of ice and the ice slab beneath. (Analogously, for an ice block on a surface other than ice, the initial peak resistance could be associated with static friction.)

For each test, a normally loaded block of ice was placed on the ice surface and, after a prescribed period, was loaded horizontally, by way of a cable tow, until the freeze-bond sheared. Each test was repeated at least ten times in order to establish one data point.

\section{PRESENTATION AND DISCUSSION OF RESULTS}

The results from the experiments are presented and discussed in terms of the influences on freeze-bonding of the following parameters:

(i) contact period (for $\sigma=460 \mathrm{kPa}$ );

(ii) normal pressure (for a contact period of $10 \mathrm{~s}$ );

(iii) fluid at contact (air, pure water, river water, saline water, all at $\left.0^{\circ} \mathrm{C}\right)$; and,

(iv) contact area.

Preliminary tests were carried out to examine the influence of loading speed on strength of a freeze-bond between the test ice block and the base ice slab. The range of loading

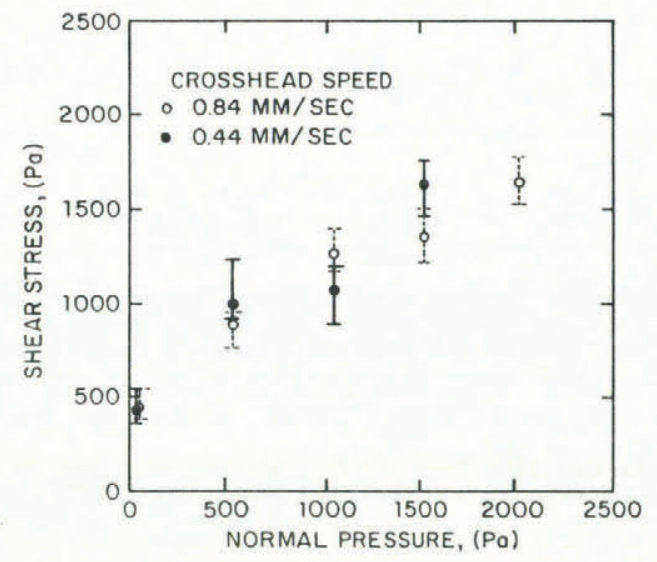

Fig. 6. Influence on freeze-bond strength of the rate of loading rate, for the range of strain-rates tested.

speeds was limited to a relatively narrow range; $0.84 \mathrm{~mm} / \mathrm{s}$ to $0.44 \mathrm{~mm} / \mathrm{s}$. For this range, loading speed did not influence the measured strength of the freeze-bond between the ice block and the ice base, as shown in Figure 6.

Each datum point given in Figures 7 through 15 is the mean of ten tests at the given test condition.

\section{Influence of contact period}

The force required to shear the freeze-bond between the test block and the ice slab increased with increasing contact period when the freeze-bond formed in water. When the freeze-bond formed in air, its strength increased weakly with increasing contact period, and reached an asymptote of $450.4 \mathrm{~Pa}$ within $3 \mathrm{~min}$ of contact. These results are presented in Figure 7.

\section{Influence of normal pressure}

For the range of normal pressures used in the present study, the shear strength of the freeze-bond increased linearly with increasing normal pressure, as shown in Figure 8. Significantly stronger bonds formed between the ice block and the ice surface when freeze-bonding occurred in either distilled water or tap water than when it occurred in air.

The data indicate that the following relationships can be written for the strength of freeze-bonding:

$$
\tau=F_{\mathrm{S}} / A=k \sigma, \quad \text { for } \sigma \leqslant 3.5 \mathrm{kPa}
$$

where $k$ is a coefficient of proportionality, for distilled water, $k=2.01$, for tap water, $k=1.95$, and for air, $k=$ $0.48 ; F_{S}$ is force to shear the ice block from the ice base, and $A$ is base area of the test block of ice.

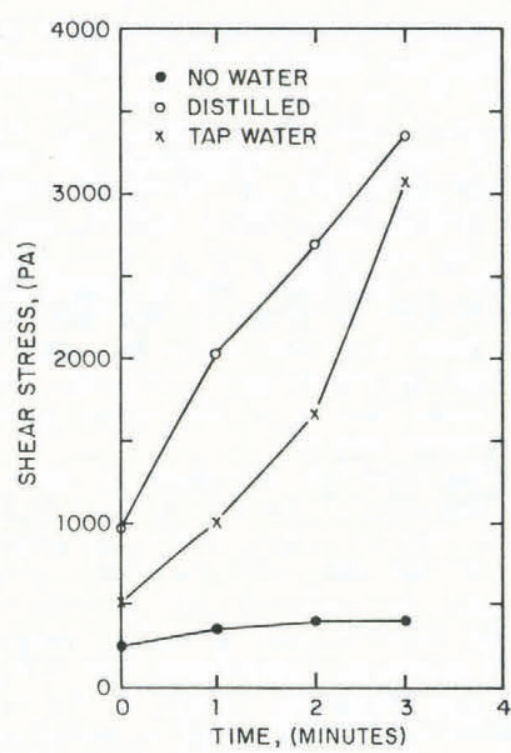

Fig. 7. Strength of freeze-bond versus period of contact. 


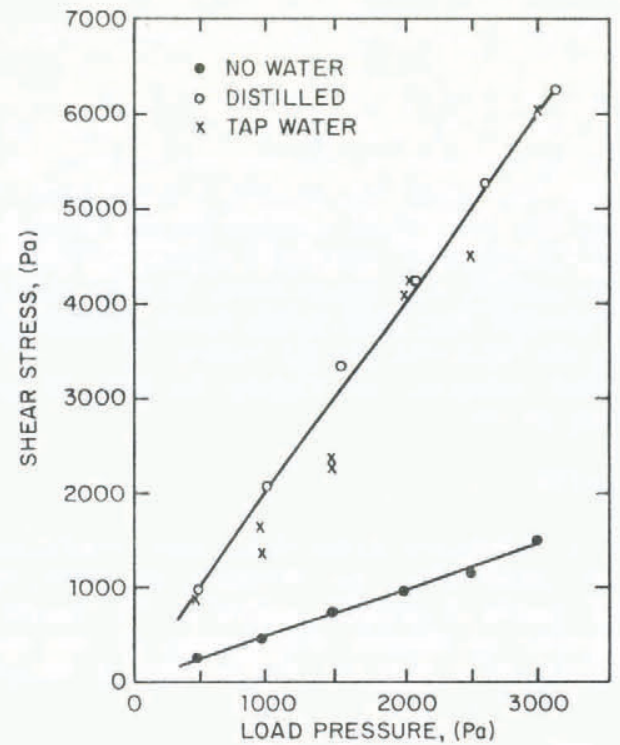

Fig. 8. Strength of freeze-bond versus normal pressure: freeze-bonding in distilled water, tap water, and air.

By way of comparison, if freeze-bonding did not occur, Equation (4) suggests that, for ice blocks contacting in air, $k=\mu_{\mathrm{S}}=0.1 ; \mu_{\mathrm{S}}$ may be less than 0.1 for ice contacting in water, if no freeze-bonding occurs.

The data (Fig. 8) show that, for the same period of bonding, freeze-bonds formed between the ice blocks in water were about four times stronger than those formed between ice blocks in air.

Examination of the test blocks, after they were sheared from their freeze-bonded contact at the ice base, revealed a rounding of the side edges (parallel to the direction of shear) at the contact surfaces with a protrusion of ice beyond the original rectangular edges. Figure 9 shows a $9.01 \times 10^{-3} \mathrm{~m}^{2}$ contact-area block (medium-size ice block) prior to, and after, an experiment. The top surface of this block was the contact surface. Note that the rounded and somewhat serrated edges indicate that freeze-bonding had occurred between the test block and the ice surface upon which it was seated. During this test, freeze-bonding occurred in tap water.

A similar comparison is depicted in Figure 10 for the largest size test block. For each set of photographs (Figs 9 and 10), the differences in the edge conditions of the test blocks show that the test block had freeze-bonded to the ice base.

\section{Influence of water salinity}

The strength of the bond formed between the test block and the ice surface decreased with increasing salinity of water in which freeze-bonding occurs. This result is evident in Figures 11 and 12, for the following test conditions: water temperature $=0^{\circ} \mathrm{C}$, rate of loading

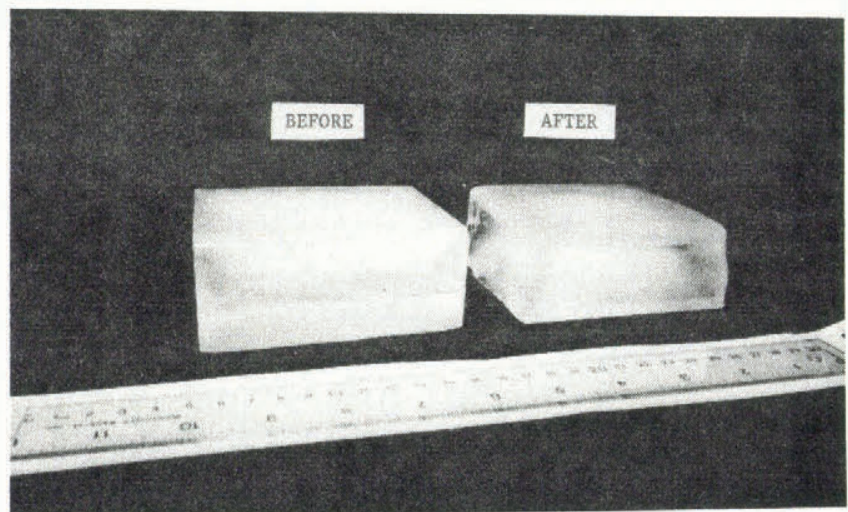

Fig. 9. Condition of a medium-size test block of ice before and after a test.

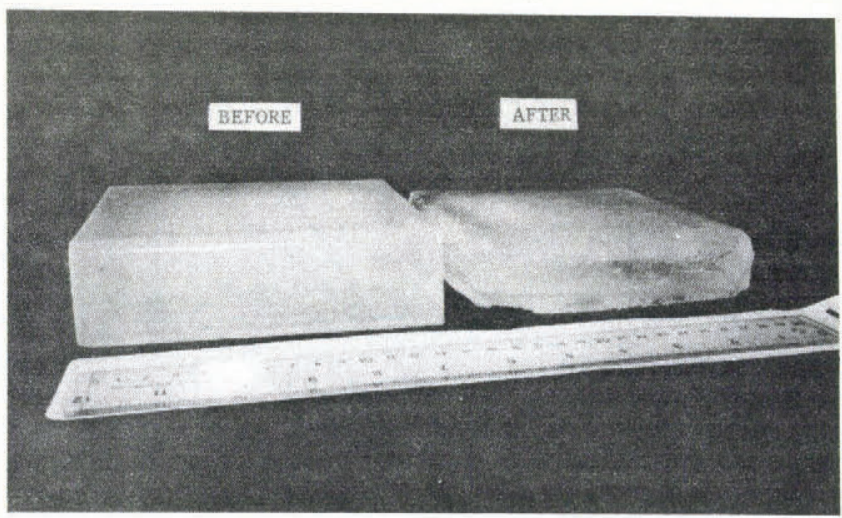

Fig. 10. Condition of a largest size test block of ice before and after a test.

$=0.84 \mathrm{~mm} / \mathrm{s}$. In Figure 11, normal pressure on the test block was $450 \mathrm{~Pa}$. In Figure 12, the contact period was $10 \mathrm{~s}$.

When freeze-bonding took place in distilled water and in water from the Iowa River, freeze-bond strength increased linearly with period of freeze-bonding up to $3 \mathrm{~min}$ (Fig. 11). When freeze-bonding occurred in a $3 \%$ (by weight) saline solution, the strength of the freeze-bond reached an asymptotic value of about $650 \mathrm{~Pa}$. For freeze-bonding occurring in saline water with salinities in excess of $12.5 \%$, the strength of freeze-bonding did not increase with time of contact but remained at about $200 \mathrm{~Pa}$ (for $\sigma=450 \mathrm{~Pa}$ ).

The influence of normal pressure, $\sigma$, on strength of freeze-bonding diminishes with increasing salinity of water, reaching a lower asymptote which is a function of normal pressure, o. Figure 12 illustrates this trend.

For 2-4 min periods of contact, the freeze-bond formed in 12.5 and $25 \%$ saline solutions, at $0^{\circ} \mathrm{C}$, was about half the strength of the freeze-bond formed in air, or for a dry surface, at $0^{\circ} \mathrm{C}$. By comparing Figures 12 and 8 , it can be seen that freeze-bonds formed in 12.5 and $25 \%$ saline solutions, at $0^{\circ} \mathrm{C}$, are about $60 \%$ less strong than are freeze-bonds formed between dry ice blocks.

For freeze-bonding between ice blocks, Equation (5) can be broadened to include the effect of water salinity, i.e.

$$
F_{\mathrm{S}} / A=\tau=2.01(1-0.06 C) \sigma, \text { for } C<12.5 \%
$$

and

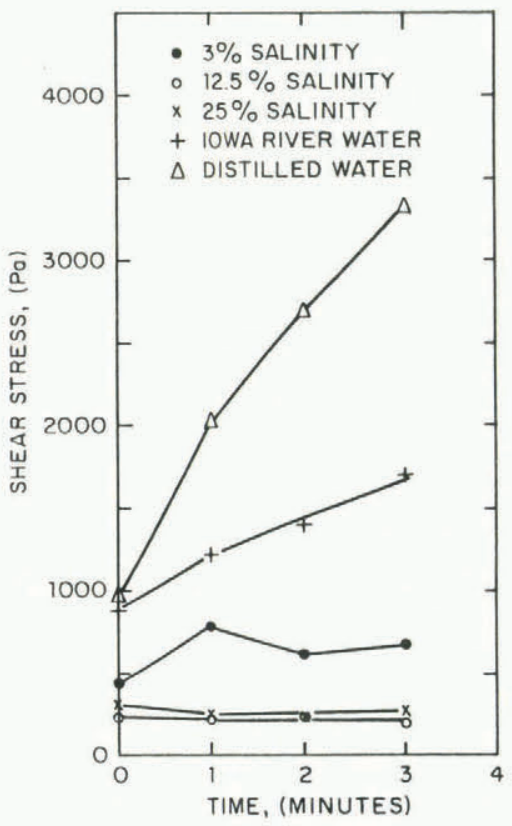

Fig. 11. Strength of freeze-bonding versus contact period for freeze-bonding in saline solutions at $0^{\circ} \mathrm{C}$ with normal pressure of $3.8 \mathrm{kPa}$. 


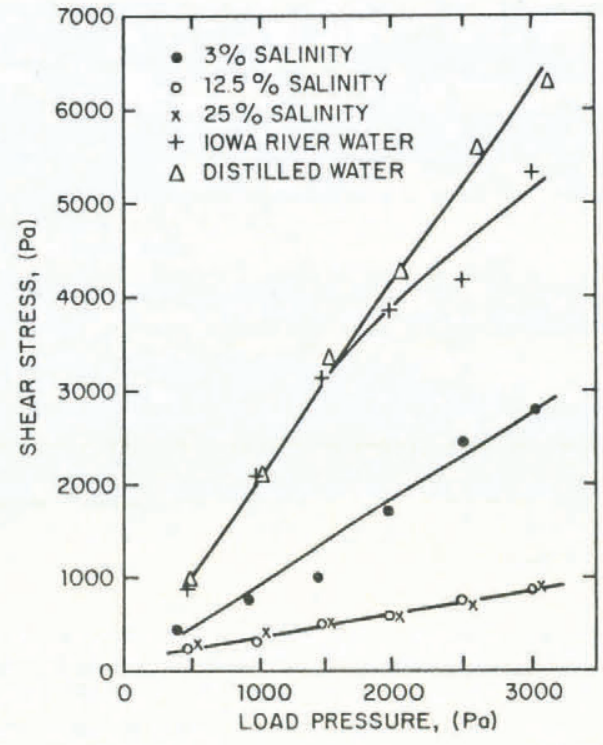

Fig. 12. Strength of freeze-bonding versus normal pressure for freeze-bonding in saline solutions at $0^{\circ} \mathrm{C}$ for contact period of $10 \mathrm{~s}$.

$$
F_{\mathrm{S}} / A=\tau=0.280, \text { for } C \geqslant 12.5 \%
$$

in which $C$ is concentration of salt as per cent by weight.

\section{Influence of contact area}

A clear relationship between block size, contact time, and strength of freeze-bonding in tap water is difficult to discern from Figure 13. It appears that, at first contact, a stronger bond formed for the two smaller test blocks. However, with increasing time of contact, the freeze-bond formed by the two smaller ice blocks and the ice base strengthened at a slower rate than did the freeze-bond forming between the largest ice block and the lower ice surface.

The experiments also indicate that there is no discernible influence of contact area on the relationship between normal pressure and strength of freeze-bonding between the blocks contacting in air. Figure 14 shows that, for each of the three contact areas, freeze-bond strength

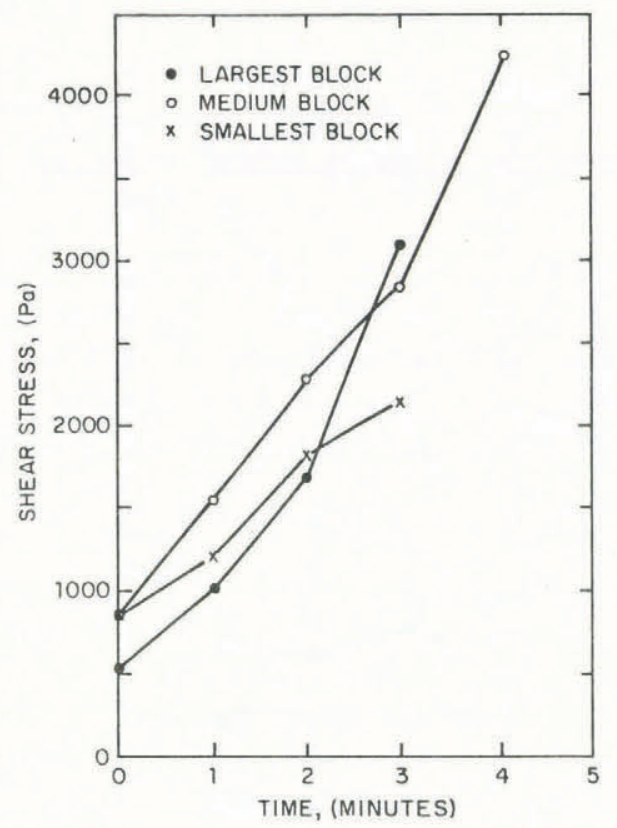

Fig. 13. Strength of freeze-bonding versus contact period for three sizes of test ice block: freeze-bonding in tap water at $0^{\circ} \mathrm{C}$. increased linearly, and more or less equally, with normal pressure.

Normal pressure more profoundly influenced the strength of the freeze-bond between the largest ice block and the ice surface than it did for the smallest ice block (see Fig. 15). This result was possibly brought about by the squeezing of the water from between the ice block and the ice surface. Consequently, because a greater surface area of ice was in contact, the freeze-bonds became colder and, therefore, stronger than the freeze-bonds formed between the smallest ice block and the ice surface.

The data presented in Figures 14 and 15 are for contact times of $10 \mathrm{~s}$.

\section{CONCLUSIONS}

Series of laboratory experiments were conducted with the aim of determining the influence on freeze-bonding between ice blocks of pressure normal to the contact plane, period and area of contact, and salinity of the water in which freeze-bonding occurred. Freeze-bonding between ice

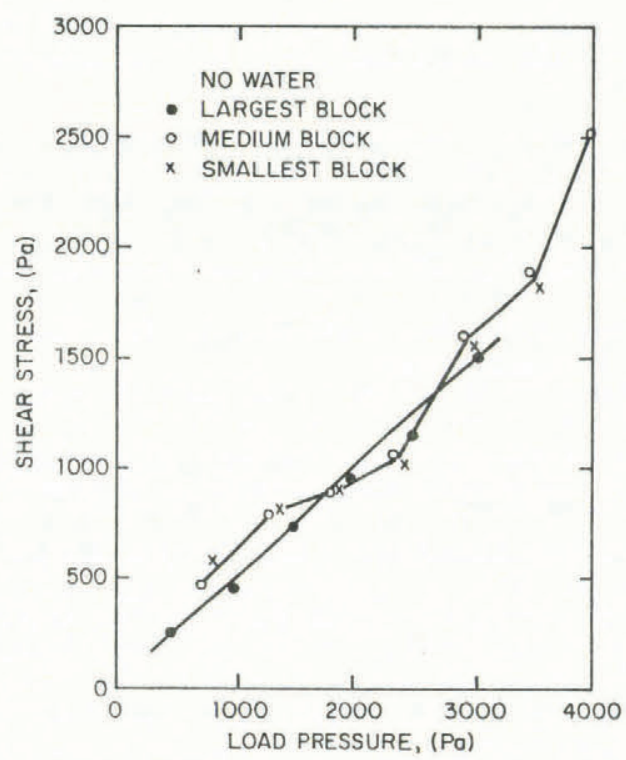

Fig. 14. Strength of freeze-bonding versus normal pressure for three sizes of test ice block: freeze-bonding for $10 \mathrm{~s}$ in air at $0^{\circ} \mathrm{C}$.

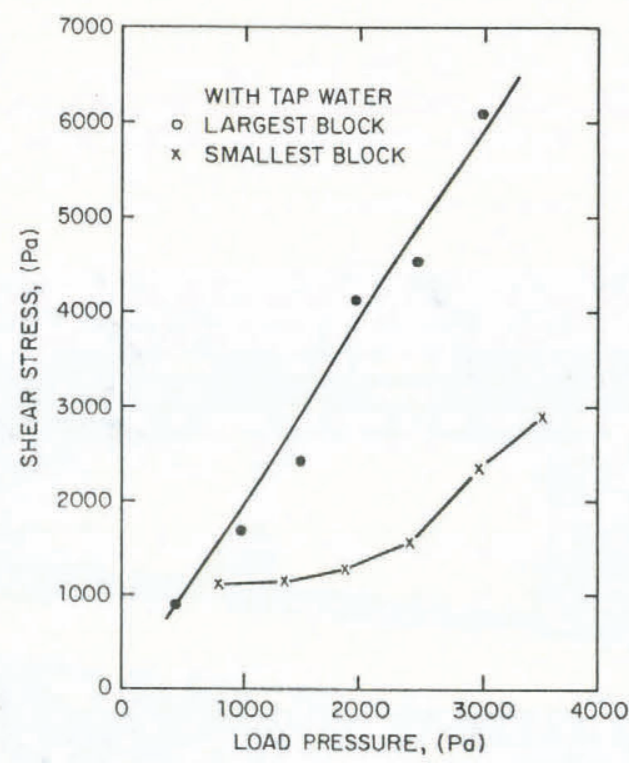

Fig. 15. Strength of freeze-bonding versus normal pressure for two sizes of test ice block: freeze-bonding for $10 \mathrm{~s}$ in tap water at $0^{\circ} \mathrm{C}$. 
blocks in air was also investigated. The experiments were conducted with water and air temperatures of approximately $0^{\circ} \mathrm{C}$, and normal pressure between ice blocks up to $4 \mathrm{kPa}$ This range of normal pressures can be associated with average contact pressures between ice blocks in a $10 \mathrm{~m}$ thick layer of floating ice rubble under conditions of hydrostatic loading, and in $2-3 \mathrm{~m}$ thick layers of floating ice rubble under conditions of passive Rankine-state loading.

The following principal conclusions were arrived at:

1. The strength of freeze-bonds between ice blocks in contact is influenced by normal pressure, contact time and area, and salinity of the water in which bonding, or fusion, occurs.

2. Stronger freeze-bonds develop between ice blocks in distilled water, tap water, and water from the Iowa River than between ice blocks contacting in air However, stronger freeze-bonds develop between ice blocks in air than develop between ice blocks in 12.5 or $25 \%$ (by weight) saline solution at $0^{\circ} \mathrm{C}$. Freeze-bonds formed in distilled or mains tap water at $0^{\circ} \mathrm{C}$ are about four times stronger than those formed in air at $0^{\circ} \mathrm{C}$.

3. For freeze-bonding between ice blocks contacting for less than $1 \mathrm{~min}$ in distilled water, strength of freeze-bond

$$
F_{\mathrm{S}} / A=\tau=2.01 \sigma
$$

and for freeze-bonding in saline solution, strength of freeze-bond

$$
F_{\mathrm{S}} / A=\tau=2.01(1-0.06 C) \sigma .
$$

For the above equations, $F_{S}$ is the force required to shear a freeze-bond; $A$ is contact area $(9.03 \times$ $\left.10^{-3} \mathrm{~m}^{2}\right) ; \quad \tau$ is nominal shear strength of freeze-bond; $\sigma$ is normal pressure acting against $A$; and $C$ is weight concentration of salt $(\mathrm{NaCl})$ in water.

4. The strength of freeze-bonding increases linearly with contact period for ice blocks contacting in distilled water, tap water, or Iowa River water.

5. The strength of freeze-bonding does not increase with contact period for ice blocks contacting in saline $(\mathrm{NaCl})$ solutions with salinity in excess of $3 \%$ for solution temperature at $0^{\circ} \mathrm{C}$.

6. The strength of freeze-bonding does not increase with contact period for ice blocks contacting in air at $0^{\circ} \mathrm{C}$.

\section{SIGNIFICANCE OF RESULTS TO THE SHEAR- STRENGTH BEHAVIOR OF A LAYER OF FLOATING ICE RUBBLE}

The conclusions enumerated above are of some significance to the shear strength and deformation behavior of a layer of floating ice rubble.

Because stronger freeze-bonds form between ice blocks in water, it is likely that the shear strength of rubble in water will exhibit a more pronounced cohesive character than will ice rubble being sheared in air. Associated with this result, it is likely that the shear-strength behavior of ice rubble in water will exhibit a greater shear-rate effect (decreasing strength with increasing rate) than will the shear-strength behavior of ice rubble in air.

The cohesive component in the shear-strength relationship for floating ice rubble may increase with increasing layer thickness of ice rubble, because normal pressures increase.
Contributing to the scatter of data on the shear-strength behavior of rubble ice is the time between tests, as with increasing contact time, stronger freeeze-bonds may develop.

Extrapolation to full scale of the data presented here is likely complicated by several factors, including the influence of core temperature of ice-rubble pieces. Further research is needed to determine the influences on freeze-bonding of core temperature, which by affecting heat fluxes from contact points likely influences freeze-bond strength, and other factors such as form and roughness of ice rubble.

\section{ACKNOWLEDGEMENT}

This study was funded by the U.S. National Science Foundation under grant No. CEE81-09252.

\section{REFERENCES}

Faraday, M. 1859. On regellations and the conservation of force. London, Edinburgh and Dublin Philosophical Magazine and Journal of Science, Vol. 17, p. 162-69.

Hellman, J.-H. [1984.] Basic investigations on mush ice. IAHR. Ice Symposium 1984, Hamburg, August 27-31, 1984. Proceedings, Vol. III. Hamburg, Hamburgische Schiffbau-Versuchsanstalt, p. 37-55.

Hobbs, P.V. 1974. Ice physics. Oxford, Clarendon Press.

Hobbs, P.V., and Mason, B.J. 1964. The sintering and adhesion of ice. Philosophical Magazine, Vol. 9, p. 181-97.

Jensen, D.C. Unpublished. On the cohesion of ice. [M.S. thesis, Pennsylvania State University, 1956.]

Keinonen, A., and Nyman, T. 1978. Basic investigations on mush ice. (In Proceedings of International Association for Hydraulic Research, Symposium on Ice, Lulea, Sweden, p. 335-55.)

Kingery, W.D. 1960. Regelation, surface diffusion and ice sintering. Journal of Applied Physics, Vol. 31, No. 5, p. 833-38.

Kuroiwa, D. 1961. A study of ice sintering. Tellus, Vol 13, No. 2, p. 252-59.

Mellor, M. 1980. Ship resistance in thick brash ice. Cold Regions Science and Technology, Vol. 3, No. 4, p. 305-21.

Merino, M.P. 1974. Internal shear strength of floating fragmented ice covers.

Nakaya, U., and Matsumoto, A. 1954. Simple experiment showing the existence of "liquid water" film on the ice surface. Journal of Colloid Science, Vol. 9, No. 1, p. 41-49

Oksanen, P. 1983. Friction and adhesion of ice. Espoo, Technical Research Centre of Finland. Laboratory of Structural Engineering. (Publication 10.)

Oksanen, P., and Keinonen, J. 1982. The mechanism of friction of ice. Wear, Vol. 78, No. 3, p. 315-26.

Pounder, E.R. 1965. The physics of ice. Oxford, etc., Pergamon Press.

Prodanovic, A. 1979. Model tests of ice rubble strength. POAC 79: the fifth International Conference on Port and Ocean Engineering under Arctic Conditions. At the Norwegian Institute of Technology. August 13-18, 1979. Proceedings, Vol. 1, p. 89-105.

Tatinclaux, J.-C., and Cheng, S.T. 1978. Characteristics of river ice jams. (In Proceedings of International Association for Hydraulic Research, Symposium on Ice, Lulea, Sweden, p. 461-75.)

Thomson, W. 1861. On crystalization and liquifaction influenced by stresses tending to change of form in crystals. Proceedings of the Royal Society of London, Vol. 11 , p. $473-81$

Uzuner, M.S. Unpublished. Hydraulics and mechanics of river ice jams. [Ph.D. thesis, University of Iowa, 1974.]

Uzuner, M.S., and Kennedy, J.F. 1976. Theoretical model of river ice jams. Journal of the Hydraulics Division, Proceedings of the American Society of Civil Engineers, Vol. 102, HY9, p. 1365-83. 